\title{
Aborigines' Dreaming or Britain's Terra Nullius: Perceptions of Land Use in Colonial Australia
}

\author{
Emily J. Pettit
}

Lieutenant James Cook of the HMS Endeavour arrived upon the eastern shore of Australia in 1770 and found a landscape and continent unlike anything seen before by European explorers. Overwhelmed and intimidated by Australia's harsh climate and desolate landscape, Cook and the British explorers and colonists who arrived later described a "formidable" land "nearly the reverse of what we find in England." "The Europeans saw this continent as a land with few people but full of potential natural resources and land awaiting delineation into property parcels for independent ownership and efficient commercial exploitation. By comparison, the original inhabitants of Australia, the Aborigines, saw a landscape created and inhabited by ancestral spirits that provided the resources necessary for survival. The differing Aboriginal and British perceptions of Australia contributed directly to how the land was used and to the environmental problems that developed as British influence increased. Australia currently struggles with the repercussions of commercialized agriculture in an arid climate, with problems ranging from erosion to groundwater pollution to extreme soil salinization. This paper compares Aboriginal and British land use perceptions and practices in colonial

${ }^{1}$ Bill Gammage, Biggest Estate on Earth: How Aborigines Made Australia (Sydney: Allen and Unwin, 2011), 5-6; J. S. Roe, "Report of an Expedition Under the SurveyorGeneral, Mr. J. S. Roe, to the South Eastward of Perth, in Western Australia, Between the Months of September, 1848, and February, 1849, to the Hon. The Colonial Secretary," in Journal of the Royal Geographical Society of London 22 (1852): 14, 17, accessed February 18, 2013, http://www.jstor.org/stable/1798198.

Honors Seminar. Professor Michaela Hoenicke-Moore. Spring 2013.

Honors Thesis. Professor Jeffrey Cox. Fall 2013.

Thesis Advisor: Professor Jennifer Sessions. Fall 2014.

Copyright (C) 2015 Emily J. Pettit

THE IOWA HISTORICAL REVIEW 
Australia to examine how the process of British settlement led to severe, widespread environmental degradation across the continent.

This paper begins with a brief historical overview of the Aborigines and their settlement of Australia beginning 70,000 to 40,000 years ago, focusing specifically on the structure of Aborigine society and their connection to the landscape. From there, this paper investigates the characteristics of Aborigine perceptions of the landscape, how such views influenced land management practices, and the resulting effects on the environment. The discussion then moves to the British colonization of Australia as it began in 1788, which provides context for the European presence on the continent. From there, the paper explores British perceptions of the land, followed by an investigation of British land management techniques and the environmental impacts of those methods. It concludes with an overview of contemporary ecological conditions, how they connect to the colonization of Australia, and what they mean for the future of Australia's environment. A timeline of significant events beginning with the arrival of the British in the eighteenth century is located in the appendix.

\section{Introduction}

As European colonists began arriving in 1788 and spread inland from coastal port towns, Aborigines found themselves competing against a rigid foreign system of property ownership for less and less available land. Aborigines were not unfamiliar with the notion of territory as property; they respected community territorial boundaries based upon ancestral occupation and the presence of sacred spiritual markers across the landscape. ${ }^{2}$ Individuals belonging to the community of a particular spiritual ancestor were free to move about within these territories in search of resources. The key difference of the introduced colonial system was the concept of individuals owning lawfully separated plots of land for commercial exploitation. British settlers, establishing large-scale farms, relied on British law and local militias to keep the Aborigines from impinging upon their newly claimed land. ${ }^{3}$

2 David Bruno, Landscape, Rock Art, and the Dreaming: An Archaeology of Preunderstanding, (London: Leicester University Press, 2002), 72, 87; Jan Roberts, Massacres to Mining: The Colonisation of Aboriginal Australia (Blackburn: Dove Communications, 1981), 4. ${ }^{3}$ James Kohen, Aboriginal Environmental Impacts (Sydney: University of New South Wales Press, 1995), 107; Roberts, Massacres to Mining, 4. 
Expanding British towns and farms were protected by fences, the settlers themselves, and British legal policies, which isolated Aborigines from their resources and sacred sites and weakened the physical and spiritual foundations of their societies. Fences and British militia groups physically prevented Aborigines from reaching parts of their ancestral territory, which cut off access to resources. Conflicts became commonplace in the nineteenth century as the Aborigines tried to find resources to survive and the British tried to prevent Aboriginal raids while producing goods for export. The result was the transformation of the coasts and other agriculturally viable regions into fragmented plots of land that upended the Aborigines' way of life and resulted in widespread ecological degradation that persists through the twenty-first century. ${ }^{4}$

British settlers were aware that they were dramatically changing Australia's landscape. Colonial officials and residents alike discussed Australia's unfamiliar flora, fauna, and climate, as well as plans for the transformation of the continent into a productive agricultural landscape fitting for a developing British colony. There is a limited amount of published colonial Australian literature prior to the 1840s, when settlement began in earnest. Many of these accounts were published back in Britain for public consumption, and reveal a conscious appropriation of Australia as a European entity in both the narrative and physical realm. European place-names and the mapping of Australia according to the European perspective of an undiscovered land coincided with a narrative separation of European settlers from the Aborigines to formalize and legitimize Britain's imperialism. ${ }^{5}$ "Eye-witness" reports served to validate generalizations about the landscape (desolate, intimidating, yet ready for transformation by British settlers) and the Aborigines (savage, uncivilized, few in number), which in turn reinforced how the British conceptualized their actions in an "empty" continent. ${ }^{6}$

It is important to note that the early colonial history of Australia suffers from a distinct lack of written Aboriginal sources, because Aborigine society

\footnotetext{
${ }^{4}$ Jonathan A. Foley et al., "Global Consequences of Land Use," Science 309 (2005): 570-71, accessed March 8, 2013, doi: 10.1126/science.1111772.

${ }^{5}$ Robert D. Grant, Representations of British Emigration, Colonisation and Settlement: Imagining Empire, 1800-1860 (Houndmills: Palgrave Macmillan, 2005), xii.

${ }^{6}$ Grant, Representations of British Emigration, xii, 3; Samuel Marsden, Memoirs of the Life and Labours of the Reverend Samuel Marsden, of Paramatta, Senior Chaplain of New South Wales; and of His Early Connexion with the Missions to New Zealand and Tabiti (London: The Religious Tract Society, 1858): 14, 256.
} 
had no written tradition. Aboriginal rock art offers a limited glimpse into elements of Aborigine society, particularly the Dreaming-i.e. the intimate connection of revered ancestral spirits, social mores, and the surrounding landscape that permeated every aspect of the lives of Aborigines. ${ }^{7}$ Information about early European contact from the Aborigine perspective, however, is almost nonexistent. What information scholars have collected about early Aborigine-British interaction comes from the British perspective, specifically that of literate British colonial society; not all British settlers could write-or chose to write-about their experiences. This paper relies on the observations of a small portion of colonial Australia's population, those by explorers and missionaries, and makes use of photographs to provide insight into Aboriginal rock art and environmental conditions. These are European sources, and therefore carry an inherent bias in perspective and narrative concerning the Aborigines and the land and must be treated with caution. Explorers and missionaries were the among the first to move into the continent's interior and have extensive contact with Aborigines, so their journals and reports are particularly relevant to this topic because they reveal not only the earliest perceptions of the Aborigines themselves, but also the condition of the Australian landscape prior to extensive colonial modification. Photographs assist in this regard, showing not only what settlers thought noteworthy at the time, but also providing visible information about the condition of the continent that might not otherwise be explained in written records.

\section{An Aboriginal Continent}

The Aborigines of Australia have a long, interconnected history with the continent that scholars generally accept as beginning between 50,000 and 60,000 years ago, when the first Aborigines reached the shores of Sahul, a massive continent consisting of Australia, Tasmania, New Zealand, and New Guinea. ${ }^{8}$ Based on archaeological evidence, a growing number of scholars deem it unlikely that the scattered Aboriginal population had a significant

7 The Dreaming is a key foundation of Aborigine culture and society; it is a framework for conceiving space and behavioral expectations in their society that ties individuals together with ancestral spirits and the landscape, which embodies not only a means to survive but also the physical manifestation of the spiritual realm. The term itself is an incomplete translation of many Aborigine terms that cannot be translated word-to-word. I will use "the Dreaming" in this paper because it is the most commonplace term used.

${ }^{8}$ Kohen, Aboriginal Environmental Impacts, 15-16. 
environmental impact at that time. It was not until 6,000 years ago that the climate stabilized enough to allow Aboriginal populations to expand and settle the entire continent, by which time they had developed into a semi-nomadic society that fit in with Australia's harsh climate. ${ }^{?}$

Environmental stewardship was one of the key foundations of Aboriginal culture because the Aborigines were wholly dependent on a sensitive resource base. The Aborigines focused on cultivating the land as a source of food as well as the physical embodiment of and connection to ancestral spirits that manifested in a multitude of sacred landmarks. Distinct territories acted as a means to protect resources and reduce conflicts between groups, but controlling land was not the foundation of an individual's power or social position. Instead, most of Aboriginal societal status came from the acquisition of knowledge and one's age, which created a hierarchy of experience that ensured the smooth function of day-to-day tasks and proper observance of ceremonies. Elders provided guidance, led rituals, and passed on the customs and stories of the Dreaming, thus earning the respect and deference of younger members for continued group cohesion. ${ }^{10}$

\section{Aboriginal Groups}

British accounts cannot agree on the number of groups or individual Aborigines present in Australia in the nineteenth century, though it is estimated that there were at least 500 groups and anywhere from 200,000 to "three millions [sic]" individuals. ${ }^{11}$ By the 1891 census, there were only 38,879, though

${ }^{9}$ Ibid., 26.

${ }^{10}$ Susan Servello, "Australian Aborigines," in 21 $1^{\text {st }}$ Century Anthropology: A Reference Handbook, ed. H. Hames Birx (Thousand Oaks: SAGE Publications, Inc., 2010), 670, accessed September 28, 2013, http://dx.doi.org.proxy.lib.uiowa.edu/ 10.4135/9781412979283.n66; Watkin Tench, A Narrative of the Expedition to Botany Bay, With an Account of New South Wales, Its Productions, Inbabitants, \&r. To Which is Subjoined, A List of the Civil and Military Establishments at Port Jackson (London: J. Debrett, 1789): 41, accessed June 26, 2014, http:/ / purl.library.usyd.edu.au/ setis/id/p00039.

11 Timothy Augustine Coghlan, A Statistical Account of the Seven Colonies of Australasia (Sydney: Charles Potter, 1894) 55, accessed July 11, 2014, https://babel.hathitrust.org/shcgi/pt?id=uc1.b3292507;view=1up;seq=5; Joseph King, Ten Decades; The Australian Centenary Story of the London Missionary Society (London, London Missionary Society, 1895), 68; Roberts, Massacres to Mining, 1; Alexander Strachan, The Life of the Reverend Samuel Leigh, Missionary to the Settlers and 
this number is less than accurate due to varying criteria used to count Aborigines in different colonies and the likelihood that individuals in isolated areas were missed. ${ }^{12}$

The Aborigines developed many languages and customs unique to their family groups. The British separated and identified Aborigine groups based primarily on differences in dialect and language, because many languages were not mutually intelligible. Within these language groups were several moieties, or "skin groups," which contained distinct families that may or may not have included biologically related individuals. Some people, such as escaped convict James Buckley, were adopted into a specific Aborigine group after living with the group for an extended period of time. ${ }^{13}$ Adjacent family groups in the same moiety often intermarried, which created larger amalgamations of relatives and helped reduce conflict. Aborigine societal organization centered on kinship, particularly the notion that individuality was subordinate to the needs of the group. Families within a moiety followed "the laws of [their] own chief," which could differ from other chiefs, as well as "laws of general application" common to the other groups that pertained to territory control and resource use. ${ }^{14}$ Family support and cooperation was emphasized; every member had a role to play to provide resources, safety, or guidance for others. Once old enough, children participated in an initiation ceremony that marked the end of their childhood and recognized their adult status and readiness for adult responsibilities..$^{15}$ Among these responsibilities was a moral obligation to care for the land and to ensure future generations would have access to the

Savages of Australia and New Zealand; with a History of the Origin and Progress of the Missions in those Colonies (London, Wesleyan Mission House, 1870), 38.

${ }^{12}$ Coghlan, A Statistical Account, 68.

${ }^{13}$ William Buckley and George Langhorne, Reminiscenses of James Buckley who lived for thirty years among the Wallawarro or Watourong tribes at Geelong Port Philip, communicated by bim to George Langhorne (1837), 6, accessed March 27, 2014, http://www.cv.vic.gov.au/s tories/immigrants-and-emigrants/william-buckley/reminiscenses-of-jamesbuckley-who-lived-for-thirty-years-among-the-wallawarro-or-watourongtribes/reminiscenses-of-james-buckley-pp-6/; Rosendo Salvado and Charles Henry Edward Carmichael, A Benedictine Missionary's Account of the Natives of Australia and Oceania: From the Italian of Don Rudesindo Salvado (Rome, 1851), ed. C. H. E.

Carmichael (London: Anthropological Institute, 1878), 12, accessed March 25, 2014, http:/ / tinyurl.galegroup.com/tinyurl/EQ8T4, 12; Servello, Australian Aborigines, 670 .

${ }^{14}$ Salvado, A Benedictine Missionary's Account, 11.

${ }^{15}$ Servello, Australian Aborigines, 670. 
resources and spiritual connections necessary to survive as well as thrive. These traditions remain intact within Aborigine society today.

Each moiety controlled a distinct territory and venerated particular ancestral beings associated with their land, such as the Bunjil eagle spirit in southeast Australia, that had a special significance to their people. ${ }^{16}$ These beings could be very similar to those in other moieties because Aborigines were semi-nomadic and traded ideas and customs among groups. Separate families maintained their own portions of land, forming an "exclusive district, which is used in common by other neighbouring families who are [at] peace."17 The land presented not only a source of food and shelter but often encompassed the physical representations of a group's ancestral spirits. Aborigine control of the land differed significantly from the British system of legalized property rights. Land was a family resource maintained by all individuals in a family group - an individual could no more control private property than control the ancestral spirits. ${ }^{18}$ An individual could use the land in conjunction with and to the benefit of others, just like an individual could channel Dreaming energies, but autonomous control did not exist. Territory was not property to be bought and sold; it was a physical and spiritual home that comprised a key part of the Aborigine identity.

\section{The Dreaming}

The strength of the Aborigine connection to the landscape stemmed in large part from the Dreaming, which Western scholars have called a religious belief system, a creation story, and a spiritual framework. Anthropologists Sir Walter Baldwin Spencer and Francis James Gillen first used the term "Dreamtime" in the late nineteenth century to describe the Aborigines" conceptions of ancestral spirits, social codes, and the land. In 1972, anthropologist William Edward Hanley Stanner introduced "Dreaming" as an improved term to reflect its continuous nature. ${ }^{19}$ "The Dreaming" also comes from the indirect translation of various Aborigine terms referring to the sacred interconnections present within the customs, rituals, and mores of Aboriginal

\footnotetext{
${ }^{16}$ Servello, "Australian Aborigines," 670; Ros Stirling, "Gariwerd: Summits Old in Story," Australian Heritage, accessed July 29, 2014, http://www.heritageaustralia.com.au/magazine.php?article-429.

${ }^{17}$ Salvado, A Benedictine Missionary's Account, 12.

18 Ibid., 11.

${ }^{19}$ Servello, Australian Aborigines, 671.
} 
society. ${ }^{20}$ The Dreaming is not simply a religion; it provides a creation story, sets out social codes, cultivates connections with ancestral spirits, links humans and the landscape, and provides context for understanding the world. ${ }^{21}$ The physical landscape is only one expression of the Dreaming, where noteworthy landmarks are imbued with, and indicate the presence of, ancestral spirits with particular significance to an Aborigine group. An individual can access the energies present in the landscape by drawing on the ancestral spirit with whom they possess the strongest connection (e.g. someone born in the territory of the Kangaroo spirit, and thus imbued with the specific energies of the Kangaroo Dreaming within the greater Dreaming itself, would be able to draw on the energies of the Kangaroo spirit). Rituals, artwork, songs, and dances are also potent expressions of connections within the Dreaming, between humans, ancestral spirits, and surrounding energies, as well as the distinct Dreaming experiences of individuals. Some spirits, such as the Rainbow Serpent, appear in stories and rock art across Australia with a similar purpose and power. ${ }^{22}$ Others remain unique to specific regions or appear with significantly different forms or realms of influence, reflecting the boundaries between Aboriginal moieties and what the groups viewed as most important to their identity. ${ }^{23}$

British settlers, missionaries in particular, saw the Dreaming as either a "foolish belief" indicative of an uncivilized, underdeveloped society awash in rampant superstitions, or did not understand it as a spiritual or religious belief of any kind. ${ }^{24}$ Some missionaries realized that the traditional approach for "civilizing" the Aborigines - an enforced sedentary lifestyle, strict discipline, and systematized work-would not be an effective means for converting the natives, though such an understanding was based more on the difficulties of retaining converts than European confusion concerning the life view that was the Dreaming. ${ }^{25}$ European missionaries tried to explain the complex and circular interactions of the Dreaming by modeling it on the linear, hierarchical

${ }^{20}$ Lynne Hume, Ancestral Power: The Dreaming, Consciousness and Aboriginal Australians (Carlton South: Melbourne University Press, 2002), 28.

${ }^{21}$ David, Landscapes, Rock-Art, and the Dreaming, 4, 17; Hume, Ancestral Power, 24.

22 Servello, Australian Aborigines, 673.

${ }^{23}$ David, Landscape, Rock-Art, and the Dreaming, 70, 208.

${ }^{24}$ Salvado, A Benedictine Missionary's Account, 11; Joseph Townend, Autobiography of the Rev. Joseph Townend; With Reminiscences of His Missionary Labours in Australia (London: W. Reed, 1869), 196, accessed February 12, 2014, http://tinyurl.galegroup.com.proxy.lib.uiowa.edu/tinyurl/Ep4h0.

25 Marsden, Life of the Reverend, 82. 
Christian religious structure of a single God, but had little success. The Dreaming is based on circular relationships, an "all-at-once" conception, with events occurring simultaneously yet separately because time is fluid and nonlinear. ${ }^{26}$ Missionaries assumed the confusing lack of familiar Christian structure was simply evidence for the paucity of a serious religion among the natives. ${ }^{27}$ The Dreaming's intimate relationship with the landscape further emphasized the dissimilarities between the British and the Aborigines. The British saw the land as a source of material wealth to be gained through agricultural production and property ownership, while the Aborigines saw the land as the vessel of the energies uniting humans and ancestral spirits, the place of the origin of the Aborigine race, and the provider of resources necessary for survival.

The modern Western understanding of the Dreaming suffers from the limitations of translation, which contributes to inaccurate and over-mystified explanations that result in what anthropologist Lynne Hume calls a "monumental misrendering" of the Dreaming experience. ${ }^{28}$ Scholars are realizing that the Dreaming cannot be accurately defined in a single term because individual experiences influence the myriad ideas, customs, and rituals connected to the Dreaming as a whole. The complexity of the intertwined relationships within the Dreaming and how they connect individuals to ancestral spirits and the landscape are some of the most difficult aspects to explain, especially because there is no direct translation of the Aborigine terms available..$^{29}$ European missionaries, familiar with the linear hierarchy of the Christian religious model, could not grasp the nuances of the Dreaming even when they understood the importance of its role in Aboriginal society. Because the Aborigines lacked a written tradition, it was the missionaries' and colonists' confused explanations of the Dreaming that were passed on to Western scholars. Dismissing the Dreaming as a superstition made it easier for colonial authors to categorize the Aborigines as the antithesis to civilized European society, thereby giving tacit permission for the disenfranchisement of the Aborigines both as owners of the land and as a developed race. ${ }^{30}$ This dismissal perpetuated the lack of accurate definitions concerning the Dreaming. Many

${ }^{26}$ Servello, Australian Aborigines, 671.

${ }^{27}$ David, Landscape, Rock-Art, and the Dreaming, 18; Marsden, Life of the Reverend, 80; Salvado, A Benedictine Missionary's Account, 3 .

${ }^{28}$ Hume, Ancestral Power, 35, 164.

${ }^{29}$ David, Landscapes, Rock-Art, and the Dreaming, 15.

${ }^{30}$ Grant, Representations of British Emigration, Colonisation and Settlement, 28-29; Marsden, Life of the Reverend, 131; Salvado, A Benedictine Missionary's Account, 11. 
described the Dreaming as an ancient, prehistoric belief system and contributed to a romanticized view of the Aborigines as a timeless and uncivilized people. This is inaccurate, however, because it connotes the notion of static monotony when in reality the ideas and rituals associated with the Dreaming change to incorporate new perceptions, landscapes, and generations. $^{31}$

\section{Rock Art}

Rock art provided a visually distinctive way to tie the landscape to Dreaming stories and spirit-beings. The techniques for creating rock art involved painting, etching, "pecking," and carving images onto a variety of surfaces, including cave walls, the sides of cliff faces, tree trunks, and flat rock plateaus. ${ }^{32}$ While those works in more protected locations survive in greater numbers and in better condition, exposed carvings are by no means unusual and point toward the long-lasting durability of rock art images.

Though certain aspects of the Dreaming are found across the continentsuch as the close connection between humans, the physical landscape, and its energies-rock art provides glimpses into more local differentiations of Dreaming spirits. The Bunjil eagle painting found in southeast Australia, for example, is an image unique to that region yet embodies themes found in rock art in multiple locations across Australia. It is the only piece of rock art with a "recorded Aboriginal interpretation": Bunjil was a Dreaming spirit particular to southeast Australia that produced features of the landscape and "gave the various tribes their particular country" while also providing laws, customs, and rites to which family groups in the region adhered. ${ }^{33}$ Emphasis on a particular regional or local spirit within a larger pantheon of ancestral beings is commonplace across the continent, with differences found even between adjacent Aborigine groups. Such variety illustrates how Aborigines adapted the larger ideas of the Dreaming - creation stories, social mores, law codes—-to

${ }^{31}$ David, Landscapes, Rock-Art, and the Dreaming, 89-91.

32 David, Landscape, Rock-Art, and the Dreaming, 181; Ludwig Leichhardt, Journal of an Overland Expedition in Australia: From Moreton Bay to Port Essington, a Distance of Upwards of 2000 Miles, During the Years 1844-1845 (London: T. and W. Boone, 1847), 181, accessed January 22, 2014, http:/ / adc.library.usyd.edu.au/data2/p00050.pdf.

33 “Aboriginal Rock Art," Glenelg Hopkins, accessed July 28, 2014, www.ghcma.vic.gov.au/community/cultural-heritage/aboriginal-tools/aboriginalrock-art/. 
suit the needs of their kinship groups and to reflect the differences in their surroundings.

The location of rock art is important because it informs the overall purpose of the piece: an image could serve as a territorial marker if out in the open, while secluded caves could contain images relating to personal Dreaming experiences or sacred stories specific to a certain family group. Such variety in technique and subject matter reflects the "multiplicity of meanings" contained within the Dreaming. ${ }^{34}$ It also illustrates how rock art was a crucial medium for expressing individual experiences within the larger cultural context of the Dreaming as well as marking territorial boundaries through the prevalence of particular images used by disparate Aborigine groups. An important tenet of the Dreaming is that certain spirits have regions within which they are the most accessible and thus hold more power, often tied to land formations of note, such as an unusually shaped mountain like Mount Uluru (Ayers Rock). ${ }^{35}$ An Aboriginal group living in the area of the Kangaroo spirit, for example, would use its image in works of rock art to draw on the energies of the spirit, show respect for its presence, and connect with the Dreaming aspects associated with the Kangaroo. Another group, though sharing the Kangaroo as one of many ancestral spirits, may instead be associated with the Emu spirit. The Dreaming is flexible, inclusive, and dynamic, all traits that complemented the Aborigines' mobile lifestyle.

Depictions of flora, fauna, and the landscape are common components of many rock art pieces. Images of natural objects may be for practical purposes, such as indicating where water can be found, or in a more spiritual setting such as a pictorial representation of an ancestral spirit story. Animals appear frequently perhaps due to their significance as spirit-beings associated with the Dreaming as well as sources of food, illustrating how the Aborigines acknowledged the larger world within which they resided. Birds, kangaroos, snakes, and a variety of other species populate rock art works dating back thousands of years. Many art pieces include the entire animal, while others include only a footprint as a repeated motif within a larger story. Painted or engraved human figures are also a common component, in addition to outlined hand shadows or stencils.

\footnotetext{
${ }^{34}$ Hume, Ancestral Power, 36.

${ }^{35}$ Ibid., 27-28.
} 
Rock art is a medium well suited to the mobility of Aborigine groups as well as to their awareness of and respect for the landscapes they encountered. Rock art is flexible enough to adapt to purposes ranging from sensible maps to the illustration of sacred creation stories. This flexibility lent itself to the development of different artistic traditions that helped mark territorial boundaries without the need for manufactured physical barriers. The land provided the canvas, tools, and inspiration for rock art, while the Aborigines added their personal Dreaming experiences and traditions to these pieces in such a way that they connected land, human, and spirit.

\section{Working with the Land}

The assumption that Aborigines left the landscape in pristine condition is an oversimplification of their role as modifiers of the local environment, though their careful management of natural resources did much to prevent extensive overexploitation. They changed vegetation communities and the types of fauna present in their territories by burning grasslands and forests, digging water channels and earthen traps, and selectively hunting animals such as kangaroos, opossums, and emus. ${ }^{36}$ Aborigines used a variety of techniques to gather a variety of resources, and these techniques had been developed for use specifically in Australia and were flexible enough to fit the demands of various landscapes across the continent. The Aborigines adopted a seminomadic lifestyle to take full advantage of what the landscape had to offer at any one time. They were not true nomads; they returned to favored camps in particular locations and had defined territories whose limits respected the boundaries of neighboring groups. To trespass on another group's land was to provoke an attack, but it was possible to cross if the moving group first asked permission. ${ }^{37}$ The mobile lifestyle of Aborigine groups was both a response to the unpredictable climate of Australia and a means to sustainably extract resources from fragile ecosystems. Having distinct territories meant Aboriginal groups could control the degree of resource extraction and modify the foraging techniques used to suit the ecosystem in use. Such control was crucial for

${ }^{36}$ Buckley, Reminiscenses of James Buckley, 8; Kohen, Aboriginal Environmental Impacts, 9596; Leichhardt, Journal of an Overland Expedition, 224; Stirling, "Gariwerd: Summits Old in Story"; Tench, Narrative of the Expedition to Botany Bay, 38; Townend, Autobiography of the Rev., 196.

${ }^{37}$ Salvado, A Benedictine Missionary's Account, 12. 
preserving resources, especially water and food, which were driving forces behind the pattern of Aborigine settlements spread across the continent. ${ }^{38}$

Resource utilization focused on the most abundant plants and animals in each region, producing noticeable differences in Aborigine lifestyles. British colonists encountered a greater number of Aborigines closer to the coasts; while these locations were often resource-rich, coastal moiety ranges were more limited than in the interior of the continent where fewer settlers ventured. The vastly variable seasonal precipitation and temperature patterns of western Australia resulted in fewer large inland bodies of water and poorer-quality soil. Aborigine groups in eastern Australia could take advantage of the moist climate and large inland rivers, unless the El Niño-Southern Oscillation, a reoccurring period of warmer-than-average Pacific Ocean temperatures that modifies climate patterns around the world, produced prolonged drought conditions. ${ }^{39}$ Some semi-permanent modifications, such as digging canals to direct fish into traps or using fire to influence plant communities, were used by groups all across the continent because these techniques could increase forage returns without jeopardizing the source of food. Overall, Aborigines understood that foraging required a delicate balance between the acquisition of enough resources for their survival and the permanent destruction of these natural resources.

Different regions dictated the reliance on different resources. The landscape of coastal eastern Australia consisted of eucalyptus forests and lush grasslands in river floodplains like that of the Darling River. Though some areas, such as the British-named Botany Bay, were unsuitable for prolonged settlement or use, the coasts generally provided a wide variety of plant and animal food sources. Aborigine groups along the coasts even engaged in some limited cultivation, such as replanting yams along the Hawkesbury River, but it

${ }^{38}$ Ann Curthoys, "Indigenous Subjects," in Australia's Empire, ed. Deryck M. Schreuder and Stuart Ward (Oxford: Oxford University Press, 2008), 80; Leichhardt, Journal of an Overland Expedition, 53, 60; John Joseph William Molesworth Oxley, Journals of Two Expeditions into the Interior of New South Wales: Undertaken by Orer of the British Government in the Years 1817-18 (London: John Murray, 1820), 21, 28, accessed January 22, 2014, http://purl.library.usyd.edu.au/setis/id/p00066.

39 "What is an El Niño?", National Oceanic and Atmospheric Administration, accessed April 25, 2015, http://www.pmel.noaa.gov/tao/elnino/el-ninostory.html; Stuart Macintyre, A Concise History of Australia (Cambridge: Cambridge University Press, 2004), 15. 
was not the predominate source of food since these groups retained a transitory pattern of movement. ${ }^{40}$ Plant cultivation in the arid interior ecosystems was not attempted because of limited water availability (both of surface water and precipitation) and poor soil quality. In these areas, hunting emus, opossums, and kangaroos provided an important staple of the Aborigine diet. Paying attention to the distribution of preferred plants, such as wild oats, the "honeybearing Banksia," burrawang, yams, and tuber-bearing lilies, allowed Aborigines to move in patterns that gave these less resilient areas time to recover and still provide resources when needed. ${ }^{41}$

\section{Fire}

Purposefully setting fires to influence vegetation communities and prey animal distributions was one technique common across Australia. An established tradition of semi-nomadism permitted the use of fire as a land management tool because itinerancy gave Aborigines the flexibility to move away after burning a section of land. They would leave it to regrow, returning later to take advantage of vegetation that benefitted from enriched soil and decreased herbivory. Fires were also a useful means of both flushing prey out of hiding and attracting animals to the regrown vegetation, making hunting easier and less energy-intensive. ${ }^{42}$ These burns were not the results of accidents or chaotic fire starting; Aborigines were intimately aware of the interplay between fire behavior and the environment. They planned burns based on season, weather conditions, vegetation communities, and topography to ensure the fire would not turn into an uncontrollable conflagration. ${ }^{43}$ Rivers, waterholes, and hills provided natural barriers that controlled the expansion of

${ }^{40}$ Ibid., 37.

41 "Aboriginal Bush Foods," The Royal Botanic Gardens and Domain Trust, accessed July 28, 2014, http://www.rbgsyd.nsw.gov.au/plant_info/aboriginal_bush_foods; Edwin Carton Booth, Australia (London: Virtue and Company, Ltd., 1876), 338, accessed June 13, 2014, https://ia802709.us.archive.org/23/items/australia02boot/australia02boot.pdf; Roe, "Report of an Expedition," 44.

${ }^{42}$ Leichhardt, Journal of an Overland Expedition, 196; Oxley, Journal of Two Expeditions, 135.

${ }^{43}$ Marcia Langton, "Earth, Wind, Fire, and Water: The Social and Spiritual construction of Water in Aboriginal Societies," in The Social Archaeology of Australian Indigenous Societies, ed. Bruno David, et al. (Canberra: Aboriginal Studies Press, 2006), 157-58; Leichhardt, Journal of an Overland Expedition, 195. 
fires in addition to providing secure places to forage and replenish supplies. Controlled burns occurred away from settlements, a precaution that protected camps. ${ }^{44}$ Such considerations required intimate knowledge of the landscape and fire behavior, knowledge that Aborigines cultivated as part of their cultural connection with the land through the stories and customs of the Dreaming, as discussed earlier.

It is important to note, however, that Aboriginal use of fire has been a source of debate among scholars because it is difficult to discern exactly how much Aborigines used fire as a tool and how much they took advantage of naturally occurring wildfires. Some scholars argue that Aborigines did not use fire at all and that vegetation changes occurred in response to climate fluctuations during the last 50,000 years. Others maintain that fires were the product only of natural phenomena such as lightning strikes, but the placement and size of burned locations challenges these arguments. ${ }^{45}$ The majority of scholars support the assertion that Aborigines intentionally set fires to facilitate better foraging conditions, "no doubt connected with a systematic management" of their territory. ${ }^{46}$ British explorers wrote of vegetation discrepancies that could not be explained as natural phenomena. Instead of tangled snarls of underbrush, trees were spread far enough apart that creating a farm could occur without cutting a single tree. ${ }^{47} \mathrm{Cook}$, and many subsequent naturalists and explorers alike, were intrigued by vegetation growth patterns because plant distributions suggested the occurrence of fires: scrub grew where trees seemed more likely to prosper, forest undergrowth was minimal, burned grasslands appeared frequently, and fire-resistant species grew adjacent to nonfire resistant species. ${ }^{48}$ However much Aborigines used fire as a landmanagement tool, its probable role provides a crucial example of how Aborigines co-opted natural forces to the benefit of their survival instead of overwhelming natural systems with practices ill-suited to the continent. The arrival of Europeans in the late eighteenth century irreparably upended the

${ }^{44}$ Leichhardt, Journal of an Overland Expedition, 195-196.

45 Gammage, Biggest Estate on Earth, 158; Kohen, Aboriginal Environmental Impacts, 41, 108.

${ }^{46}$ Leichhardt, Journal of an Overland Expedition, 195.

${ }^{47}$ James Cook, Captain Cook's Journal During His First Voyage Round the World Made in H. M. Bark "Endeavour" 1768-71 - Literal Transcription of the Original MSS. With Notes and Introduction, ed. W. J. L. Wharton (London: Elliot Stock, 1893), n.p., accessed March 13, 2014, http://www.gutenberg.org/files/8106/8106-h/8106-h.htm\#ch8, n.p.; Gammage, Biggest Estate on Earth, 5.

${ }^{48}$ Gammage, Biggest Estate on Earth, 5-6; Oxley, Journal of Two Expeditions, 24, 26. 
balance between resource growth and extraction so carefully managed by the Aborigines.

\section{British Colonization}

The British were not the first Europeans to encounter Australia, though they were by far the most dominant. Spanish, Portuguese, and Dutch ships had been traversing the Pacific since the fourteenth century, though it was the Dutch who mapped "New Holland," as they called it, the most extensively of any European nation by the seventeenth century. ${ }^{49}$ The first British arrival occurred in 1768, when Lieutenant James Cook landed on the shores of eastern Australia. ${ }^{50}$ Two years later he formally claimed the entire continent for Britain, but Australia did not officially become part of the British colonial empire until October 12, 1786, when King George III appointed Captain Arthur Phillip as governor. ${ }^{51}$ Colonial Australia is often described as a convict colony, a place where the British government sent criminals to live out their sentences. While some towns such as Botany Bay did begin as exclusively convict outposts, others accepted convicts only to bolster their labor forces. The arrival of the "First Fleet" of convicts at Botany Bay in 1788 began a trickle of immigration that would turn into a wave as thousands of settlers eventually immigrated to Australia. ${ }^{52}$ Coastal growth expanded along major waterways, eventually culminating in the creation of five colonies: New South Wales (founded in 1788), Western Australia (1829), Victoria (1834), South Australia (1836), and Queensland (1859). ${ }^{53}$ Immigration rates to Australia as a whole were relatively steady by 1852 as people traveled to the continent to reunite with family members and take advantage of socioeconomic opportunities. The eastern colony New South Wales received the most immigrants, due in part to its more

${ }^{49}$ Macintyre, A Concise History of Australia, 21.

${ }^{50}$ Stuart Banner, Possessing the Pacific: Land, Settlers, and Indigenous People from Australia to Alaska, (Cambridge: Harvard University Press, 2007), 14.

${ }^{51}$ Alan Atkinson, "Conquest," in Australia's Empire, ed. Deryck M. Schreuder and Stuart Ward (Oxford: Oxford University Press, 2008), 33.

52 Macintyre, A Concise History of Australia, 20; Roberts, Massacres to Mining, 13-14; Strachan, The Life of the Reverend Samuel Leigh, 38.

53 Atkinson, "Conquest," 33-34; Booth, Australia, 10; John Wrathall Bull, Early Experiences of Life in South Australia, and An Extended Colonial History (Adelaide: E. S. Wigg and Son, 1884), viii; Coghlan, A Statistical Account, 1;"European Discovery and the Colonisation of Australia," Australia.gov.au, accessed August 23, 2013, http://australia.gov.au/about-australia/australian-story/european-discovery-andcolonisation; Roberts, Massacres to Mining, 20-23. 
developed infrastructure and early founding, followed closely by Victoria. Though Western Australia was the second colony founded, it remained the least populated due to the lack of established land-based transportation routes from the eastern colonies, unreliable water resources, and large temperature fluctuations that made agriculture a far more daunting task. ${ }^{54}$ Excluded from these counts of incoming Western European immigrants, who made up the majority of migrants through the nineteenth century, are those who perished en route to the continent. The passage from Europe was particularly long and dangerous, while seasonal storms in the Indian and Pacific Oceans threatened ships arriving from Southeast Asia. It was common for passengers to die from disease or poor nutrition, or for entire ships to be lost.

Settlers were not exclusively British, though they formed the majority of individuals from Western Europe. Individuals from Scotland, Ireland, China, Germany, Russia, Spain, and Turkey, among many others, formed urban enclaves or set up homesteads in the interior. ${ }^{55}$ Early settlers in the eighteenth century were often single men searching for a new life and the means to move up in society, or looking to expand their wealth beyond Britain. The harsh living conditions awaiting settlers meant many either died within their first year or left the colony. Conditions were so challenging in the early years of settlement that some officials requested that "the helpless and inefficient" not immigrate until towns could better provide for residents. ${ }^{56}$ There was little immigration in the late eighteenth and early nineteenth centuries, so it was not uncommon for former convicts to hold prominent positions in colonial society. Their early arrival in many colonial towns and their familiarity with living conditions gave them a substantial advantage over later free settlers. ${ }^{57}$

${ }^{54}$ Coghlan, A Statistical Account, 55.

55 Bull, Early Experiences of Life, 87; Coghlan, A Statistical Account, 69, 74-75; Thomas Livingstone Mitchell, Journal of an Expedition in the Interior of Tropical Australia: In Search of a Route from Sydney to the Gulf of Carpentaria (London: Longman, Brown, Green, and Longmans, 1848), 11, accessed July 10, 2014, http://purl.library.usyd.edu.au/setis/id/mitjour; Townend, Autobiography of the Rev., 230-231.

56 John Barrow, "State of the Colony of Swan River," Journal of the Royal Geographical Society of London 1 (1831): 9, accessed March 31, 2013, http://www.jstor.org/stable1797655; Godfrey Charles Knight, Western Australia Year Book for 1886 (First Year of Issue) (Perth: Richard Pether, 1887), 2, accessed July 11, 2014, http://www.abs.gov.au/AUSSTATS/abs@.nsf/DetailsPage/1300.51886?OpenD ocument.

${ }^{57}$ Marsden, Life of the Reverend, 21; Townend, Autobiography of the Rev., 187. 
Many immigrants were unprepared for the hard work necessary to survive and lacked the material goods and kinship support systems they had back in Britain, which made daily life an intimidating challenge. ${ }^{58}$ Diseases such as measles decimated towns (and ravaged Aborigine groups that lacked immunity), while the unfamiliar climate made agriculture extremely precarious. The arid interior of western Australia in particular was inhospitable for crop agriculture, so settlers turned to raising sheep and eventually turned ranching into a lucrative export business that was a key source of income for the colony. ${ }^{59}$ Social status in new colonial towns depended more on time of arrival and personal connections rather than wealth per se, which enticed many lower-class citizens to immigrate. Missionaries wrote of shiploads of new arrivals that chanced the journey and cut all ties with their homeland, often to find that towns were unprepared to assist so many poor immigrants. ${ }^{60}$ Coastal towns such as Melbourne struggled to deal with particularly heavy inflows of "three and four thousand persons... in a single week," which strained both resources and social order. ${ }^{61}$ As towns and infrastructure developed along the coasts, however, shipping and trade provided economic opportunities that made life easier.

\section{Terra Nullius}

Terra nullius, the idea of an "empty continent," was both a cultural and legal theory behind British land acquisition in Australia. ${ }^{62}$ It was "the common belief...that this was a land hitherto belonging to no one," that Australia was a "desolate" land without any recognizable owner or even a large population of

${ }^{58}$ Knight, Western Australia Year Book, 12; Townend, Autobiography of the Rev., 156; Tench, Narrative of the Expedition to Botany Bay, 62.

${ }^{59}$ Macintyre, A Concise History of Australia, 57.

60 Tench, Narrative of the Expedition to Botany Bay, 62; Townend, Autobiography of the Rev., 141.

61 Townend, Autobiography of the Rev., 141.

${ }^{62}$ Terra nullius was a foundational tenet of British colonial land policy in Australia. Based on the ideas of Emerich de Vattel, a Swiss philosopher and author of Law of Nations, published in 1758, the British reasoned that a society with a small population and with no sedentary agricultural system, such as the Aborigines, simply could not maintain control over such large territories as were found in Australia. As Vattel argued, nonagricultural peoples residing "'in these immense regions cannot be accounted a true and legal possession,"” a contention the British relied upon to support settler claims for land and legitimize land policy laws through the nineteenth century; Banner, Possessing the Pacific, 17-18. 
natives. ${ }^{63}$ Explorer reports of limited native encounters, lack of cultivated acreage, and the commonplace discovery of abandoned huts contributed to the British impression of an open, uninhabited landscape ready for conversion into agricultural parcels. The lack of recognizable European-style delineation of territory made it easy for the British to rationalize away Aborigine claims to the land and use British legal definitions of ownership to gain control of property, forcing the Aborigines to move away from encroaching British settlements. Coming from a country with a landscape heavily modified for large-scale agricultural production, natural resource extraction, and industrialization, British settlers viewed the less densely populated Australian landscape as barren and empty, lacking the controlling influence of European agriculture and development.

As a colonization mindset based on legal definitions, terra nullius complemented the British hunger for land. Colonial officials decided that the absence of recognized property boundaries or even of any understanding by the Aborigines regarding the meaning of "property ownership" indicated to British officials that Aborigines were not landowners and therefore did not have a say in what happened to the land. A prevailing perspective of Australia, besides being a desolate land, was of a place waiting to be turned into a productive agricultural establishment to the benefit of the colonists and Britain alike. ${ }^{64}$ An empty continent meant no landowners, which in turn meant no need for political or legal recognition of the current occupants as equals. The needs of the Aborigines, labeled by explorers and settlers as primitive savages, were not considered important or worthwhile. As more British settlers arrived on the continent, searching for land-based wealth, the pressure for expansive farms and estates intensified. Impatient for the wealth to be gained by cultivating crops, settlers did not respect the "savage notions" of Aborigine territorial boundaries. ${ }^{65}$ Colonists decided they were free to take and use land as they saw fit: if an Aborigine group existed at the location, it was the Aborigines who had to leave. Most settlers felt no compunction about forcing

${ }^{63}$ Banner, Possessing the Pacific, 17; Servello, "Australian Aborigines," 670; Charles Sturt, Journal of the Central Australian Expedition 1844-1845 and An Account of the Sea Coast and Interior of South Australia, ed. Jill Waterhouse (London: Caliban Books, 1984), 51.

${ }^{64}$ Booth, Australia, 10; Townend, Autobiography of the Rev.,127.

65 "Colonel Hansons Pamphlet," The Perth Gazette and Western Australian Journal, January 12, 1833, 8, accessed September 26, 2013, http://trove.nla.gov.au/ndp/del/page/7?zoomLevel=1. 
the Aborigines out. British officials sanctioned such seizure by arguing that the lack of recognizable, European-style property meant all of Australia was open for settlement. ${ }^{66}$

Some local colonial governments, however, aware of the increasing numbers of settler attacks on Aborigines and concerned about militia operations for acquiring territory, attempted to reduce conflicts and control settler incursions by protecting Aborigines' rights to inhabit the land. General land laws restricted the areas available to settle, while property laws dictated how to buy and sell land already controlled by the colonial government. The settlers, however, often ignored laws governing land seizure and ownership. Attempts to restrain land acquisition met with vehement and sometimes violent protests. Many towns, struggling to control conflicts between Aborigines and settlers, relied on informal militias or an established British military presence to protect settlers from Aborigine ambushes and to control retaliatory strikes. ${ }^{67}$ Retribution was common on both sides throughout the nineteenth century, though the settlers succeeded in pushing Aborigines further away from their ancestral lands as the colonial population increased, expanded, and made use of British property laws to gain individual control of supposedly unoccupied territory.

\section{Property}

British colonial property laws followed the European pattern of ownership: private properties required distinct owners and land transactions were documented for legal verification and protection. The idea of privately owning a section of land permeated colonial British land laws and strongly influenced how early settlers and explorers saw Australia. In order to control property in the 1800s, a man "is to be registered as owner, and every one bona fide purchasing from him is to get an indefeasible title." 68 The idea of ownership included not only owning the physical parcel of land, but also owning the legal rights to modify or change the land as one saw fit. ${ }^{69}$ Because the British

\footnotetext{
${ }^{66}$ Banner, Possessing the Pacific, 16.

${ }^{67}$ Bull, Early Experiences of Life, 82; Townend, Autobiography of the Rev., 199-200.

68 Statement on the Land Laws by the Council of the Incorporated Law Society of the United Kingdom (London: Spottiswoode and Company, 1886), 20, accessed July 24, 2014, http://www.jstor.org/stable/60217977.

69 The Settled Land Act of 1882 was "An Act for facilitating Sales, Leases, and other dispositions of Settled Land, and for promoting the execution of improvements thereon." For a more detailed explanation, see "Settled Land Act of 1882," The
} 
government treated pre-colonization Australia as a land "uninhabited by a recognised sovereign or by a people With [sic] recognisable institutions and laws," the Aborigines were treated as individuals and not the cohesive family groups that were their actual means of organization. ${ }^{70}$ This made it difficult for Aborigines to organize and maintain their claim to their ancestral territory when faced with encroaching settlers intent on gaining individualized, documented property rights as proof of ownership.

British colonists brought their ingrained notions of legalized property ownership to Australia, notions that would underlie all the subsequent changes concerning control of the land.

British land policy specified that a landowner live on an individual portion of territory that was clearly delineated by physical and lawful means including fences and legal documentation. ${ }^{71}$ Once obtained from the Aborigines via trade or charter, land became a "civilized" commodity in a system that was out of reach of any attempts by the "uncivilized" Aborigines to regain it. Documentation such as charters and signed trade papers locked Aboriginal disenfranchisement into the written legal system as proof of ownership became the only way to ensure control of land. The Aborigines lacked a written tradition, which meant they could not read the treaties they signed and were unable to provide the required legal documentation to support their territorial claims. After acquiring control of land parcels, the British colonial government sold or granted gifts of acreage according to the personal connections and social standing of individuals, thereby fragmenting the original territories and making it exceedingly difficult for the Aborigines to claim their territory within the new legal framework that did not recognize them as equal occupants. ${ }^{72}$ As the pace of Aborigine disenfranchisement increased through the 1830s and 1840s, colonial governments - by means of land use laws—-tried to discourage direct seizure of Aboriginal land in order to accommodate the increasing

National Archives, accessed July 24, 2014, http://www.legislation.gov.uk/ukpga/Vict/45-46/38/enacted; Statement on the Land Laws, 3.

70 "Aboriginal Customary Laws and Anglo-Australian Law after 1788," in Recognition of Aboriginal Customary Laws (ALRC Report 31), Division of the Law Reform Commission Act 1973 (Sydney: Australian Government, 1986), 29, accessed July 24, 2014, http://www.alrc.gov.au/sites/default/files/pdfs/publications/ALRC31.pdf.

${ }^{71}$ Statement on the Land Laws, 34.

72 John C. Weaver, "Beyond the Fatal Shore: Pastoral Squatting and the Occupation of Australia, 1826 to 1852," The American Historical Review 101 (1996): 985-86, accessed July 29, 2014, doi: 10.2307/2169631. 
population and demands of arriving settlers. However, local officials often lacked the means or interest to enforce these laws. ${ }^{73}$ Many settlers, anxious to establish a home and income but lacking the money to buy land legally, ignored the colonial government's avenues for buying land and simply squatted in rural areas. ${ }^{74}$ Beginning in 1850, the colonial government created "reserves" in an attempt to set aside some land for the Aborigines that fit within the rigid European framework of property ownership. Such reserves, however, were not intended to grant Aborigines equal access to the land and did not provide acreages equivalent to those under British control. ${ }^{75}$

British settlers and officials used a variety of tactics to remove Aborigines from their ancestral lands. British officials entered into treaties with Aborigine chiefs with the understanding that the Aborigines were unaware of the extent of the British hunger for land and the lengths to which settlers would go to gain property. ${ }^{76}$ Many trade agreements continued to expand over subsequent years, encompassing greater tracts of land for the same number of objects. John Batman's Land Conveyance Charter from 1835 illustrates a common method for gaining land: the agreement stated that the Aborigines would give up 593,053 acres of land in exchange for blankets, knives, tomahawks, flour, and other goods. The "principal chiefs" of the Kulin nation (chosen by the British for their appearance of "chief-ness," not their actual place in Kulin society) marked it to show their agreement, but it is worth reiterating that the Aborigines had no written tradition, and thus could not read what the document actually stated about the trade or the permissions it gave for future British encroachment. ${ }^{77}$

Some settlers realized the importance of the land to Aborigines, but lacked the means or organization to change land seizure practices. Since colonists took control of the land as if it were unoccupied, they fostered a sense of ownership

${ }^{73}$ Macintyre, A Concise History of Australia, 60.

74 Weaver, "Beyond the Fatal Shore," 984.

75 Curthoys, "Indigenous Subjects," 94-95.

${ }^{76}$ Booth, Australia, 12; John Batman, Document known as the "Batman Land Deed," between John Batman and Aboriginal "chiefs" of the Kulin nation, Port Phillip area, 1835 (Port Philip: Port Philip Association, 1835), n.p., accessed July 9, 2014, http:/ / www.nma.gov.au/collections-search/display?irn=58198..

77 Batman, Document known as the "Batman Land Deed," n.p.; "Document known as the 'Batman Land Deed,' between John Batman and Aboriginal 'chiefs' of the Kulin nation, Port Phillip area, 1835," National Museum of Australia, accessed July 9, 2014, http:/ / collectionsearch.nma.gov.au/?object=58198; Townend, Autobiography of the Rev., 131. 
to the newly acquired territory, which made any attempts to restore Aborigine control unwelcome, vehemently resisted, and ultimately futile. ${ }^{78}$ Some colonial officials tried to establish Aborigines as British citizens, deserving of the same rights and respect, but the frequency of settler-native conflicts accompanying increased immigration from 1830-1850 made peaceful resolutions impossible. ${ }^{79}$ Expanding towns met with increased conflict by Aborigines struggling to preserve their space, which simply confirmed the imperialist British attitude that the "treacherous," "primitive" natives did not deserve consideration as equals. ${ }^{80}$ Many British settlers, explorers, and missionaries saw the Aborigines as savages incapable of understanding technology or embracing British lifestyles. Itinerancy was viewed as aversion to civilization; foraging indicated the Aborigines' low place in the hierarchy of human development; lack of institutionalized religion suggested an underdeveloped society; furthermore, disinterest in European practices precluded any efforts to raise the "noble savage" above its lowly status. ${ }^{81}$

\section{A Southern North America}

Colonial attitudes and practices such as denying native claims to land and acquiring territory via written treaties are strikingly similar to those techniques used by immigrants to seize land in the American colonies shortly after their founding between 1607 and 1733. American colonists also employed many of the practices later used in Australia to push the Native Americans away from expanding towns and farms along the eastern coast: violence, militia missions, formal treaties and charters, and trade of manufactured goods for land. Initially peaceful interactions along the eastern coast gave way to more violent confrontations as the Native Americans fought the continuous expansion of colonial towns and farms that left little land under native control. The rapid spread of disease was a powerful factor in the removal of Native Americans, leaving vast tracts of formerly occupied land now uninhabited. Disease played a more noticeable role in North America than Australia partly because the Native American population along the eastern coast was less mobile compared

${ }^{78}$ Curthoys, "Indigenous Subjects," 82.

${ }^{79}$ Macintyre, A Concise History of Australia, 73.

${ }^{80}$ Curthoys, "Indigenous Subjects," 84, 87.

${ }^{81}$ Marsden, Life of the Reverend, 80; Salvado, A Benedictine Missionary's Account, 4; Strachan, Life of the Reverend Samuel Leigh, 38; Townend, Autobiography of the Rev., 196. 
to the Australian Aborigines, allowing for much faster transmission of foreign diseases such as smallpox, measles, tuberculosis, and syphilis. ${ }^{82}$

Another noteworthy similarity between the Australian Aborigines and the Native Americans was the indigenous peoples' attention to the limits of the natural environment's ability to recover from man-made manipulation and the transmission of such knowledge to future generations. The landscape provided a spiritual home and medium for communicating with ancestral spirits, and was not just a repository of goods to be exploited. Both the Aborigines and Native Americans used stories and close kinship ties to cultivate a sense of responsibility and respect for the environment that ultimately helped preserve resources for future use. The British, accustomed to cultivation and industrialization, viewed the environment as a source of income and the land a platform for the extension of European authority. With the arrival of the British in Australia and North America came the introduction of intensive sedentary agriculture combined with the depredations of disease and forced removal from familiar territory, which destroyed the intimate connections between land and the identities of the Aborigines and Native Americans alike.

\section{Agriculture}

Europeans in Australia saw the continent as a source of natural resources, especially once colonies with stable economies and productive agricultural systems were established. Britain needed a new source of raw materials, having lost its American colonies and raw materials to the American Revolution beginning in 1775, so the Australian colonies developed toward the extraction of natural resources, specifically for export to Britain. Early colonial towns on the Pacific coast like Port Jackson and Sydney relied on fishing and whaling to provide a steady source of income, then transitioned to terrestrial agriculture as the labor force grew and familiarity with the environment improved. ${ }^{83}$ The drastic difference between British and Australian climates contributed to serious agricultural difficulties compounded by "exhaustion and bad management" as well as unfamiliarity with regional climatic differences. ${ }^{84} \mathrm{New}$ South Wales and Victoria benefitted from predictable precipitation and mild

\footnotetext{
${ }^{82}$ Archibald Grenfell Price, White Settlers and Native Peoples: An Historical Study of Racial Contacts Between English-Speaking Whites and Aboriginal Peoples in the United States, Canada, Australia and New Zealand (Melbourne: Georgian House, 1950), 20-21.

${ }^{83}$ Macintyre, A Concise History of Australia, 19, 36.

${ }^{84}$ Bull, Early Experiences of Life, 94.
} 
temperature changes, while the climate of the Northern Territory was proclaimed to be "extremely hot" and "unfavourable to Europeans," and Western Australia dealt with explicit wet and dry seasons. ${ }^{85}$ Early farmers had to learn about the environment as they worked, as there was little information on the environment both available and reliable. Conflicting accounts on precipitation, suitable crops, and soil types illustrate the difficulty settlers had in establishing guidelines for successful farms. So profound were agricultural challenges that many early British settlements suffered years of famine until settlers grew accustomed to the environment. ${ }^{86}$

The British agricultural system relied on producing crops and livestock products for export to Britain. As settlers became familiar with Australian climate patterns, gathering fruits and growing crops on small-scale subsistence farms gave way to large-scale agricultural production for export. Growing monocrops became the dominant system on large farms because it encouraged more efficient planting and harvesting and enabled the use of irrigation systems in particularly dry regions. ${ }^{87}$ Grain crops such as wheat, hay, and oats were the dominant cultivars across Australia with Victoria and South Australia producing the most by $1861 .{ }^{88}$ Queensland and New South Wales were well suited to sugarcane production due to their more tropical climate. ${ }^{89}$ Produce such as grapes, oranges, peaches, plums, and apricots were grown predominately in New South Wales and Victoria, with other crops such as tobacco, cotton, and rice grown in small amounts in all colonies except Western Australia. ${ }^{90}$

${ }^{85}$ Coghlan, A Statistical Account, 12, 13.

${ }^{86}$ Bull, Early Experiences of Life, 92-93; Marsden, Life of the Reverend, 14; Salvado, Benedictine Missionary's Account, 127.

${ }^{87}$ Monocrop (n): designating or relating to a system of agriculture in which a single crop is cultivated to the exclusion of any other potential harvest; "Monocrop," Oxford English Dictionary, accessed July 30, 2014, http://www.oed.com/view/Entry/246089? rskey=rJOrLz\&result=1\&isAdvanced $=$ false\#eid.

${ }^{88}$ Coghlan, A Statistical Account, 191, 200.

${ }^{89}$ Ibid., 182, 214.

${ }^{90}$ Coghlan, A Statistical Account, 183, 189, 219; Knight, Western Australia Year Book, 2223, 33; Tench, Narrative of the Expedition to Botany Bay, 57; Townend, Autobiography of the Rev., 127; Richard Waterhouse, "Settling the Land," in Australia's Empire, ed. Deryck M. Schreuder and Stuart Ward (Oxford: Oxford University Press, 2008), 55. 
The dominant challenge for agriculture was the absence of reliable water sources. Many of the crops, in particular maize, cotton, and wheat, required significant water inputs for economically productive harvests. Once farmers found reliable water sources they expanded into formerly uninhabited areas, many of which were originally left unsettled due to lack of water. Irrigation was responsible for opening up a majority of these areas to the benefit of the colonies and Britain, but at the expense of the health of the environment and lifestyle of the Aborigines. Limited surface water originally kept farms and towns near the coasts of the continent, allowing the Aborigines to continue moving through the interior, though many groups lost their most resource-rich forage grounds to European encroachment.

As agriculture expanded into the arid Australian interior, irrigation systems became a crucial investment to ensure a steady water source for livestock and crops. ${ }^{91}$ Rivers dried up or flooded unexpectedly, making it risky to graze animals nearby, and unpredictable precipitation patterns could mean months without a drop of rain. Settlers used "waterholes" and wells for more reliable sources of fresh water, but found that even these sources could dry up for days on end, especially if they were overused. ${ }^{92}$ Canals and pipe systems connected to lakes and groundwater reservoirs offset some of the risks and allowed settlers to establish permanent farms in areas formerly left uninhabited, though the environmental toll was significant as formerly reliable water sources quickly dried up.

\section{Livestock Husbandry}

In addition to growing agricultural crops for export, grazing sheep, horses, swine, and cattle was another significant source of income. Sheep and their wool in particular provided extensive revenue for the western colonies, located in areas that lacked the water resources to support irrigated crops or the forage necessary for supporting cattle herds. ${ }^{93}$ In Western Australia in particular, livestock husbandry became the dominant source of agricultural income for thousands of settlers. Sheep, cattle, horses, and swine were all brought to Australia from Britain for the purpose of providing income and exportable products. Once established, towns served as focal points of inland expansion as herds grew to contain thousands of animals. Sheep and cattle herds are of

\footnotetext{
${ }^{91}$ Coghlan, A Statistical Account, 221.

92 Oxley, Journal of Two Expeditions, 36; Townend, Autobiography of the Rev., 233.

${ }^{93}$ Coghlan, A Statistical Account, 226; Knight, Western Australia Year Book, 24.
} 
particular note in colonial accounts because those herds would come to provide a significant boost to the Australian economy through their meat, skin, and fiber. ${ }^{94}$ By 1849, Victoria colony alone included 22,000 horses, 400,000 cattle, and 7,000,000 sheep, all raised on grasslands and pastures along the coasts and major water sources. ${ }^{95}$ As the market for livestock products expanded with the growth of the colonies, it was not unusual for pastureland to extend for hundreds of miles across formerly forested regions and into less suitable environments.

Explorers venturing into the interior of Australia noted locations suitable for raising livestock because of the familiar limitation of water availability in an arid climate. Just as farmers relied on trial and error with their crop fields, so too did ranchers have to search out the best pastures suited to their livestock of choice. The collapse of a livestock herd could be just as disastrous for a town as a failed harvest, a fact that was not lost on the settlers. Herds were closely watched, and many Aborigines were killed after being caught taking livestock. ${ }^{96}$ Conflicts between the Aborigines and ranchers grew more intense as the Europeans pushed further into the interior, chasing away the animals Aborigines hunted to survive and making it ever more difficult for the Aborigines to live as they had before the Europeans arrived. The environmental toll exerted by ever-increasing herds mounted as well, resulting in barren grasslands and clear-cut forests converted into pasture. Even with such conflicts, however, the vast herds grazing across the continent symbolized progress, development, and civilization to the British, who placed the wellbeing of livestock above the survival of the Aborigines and the environment in a new Australian hierarchy. ${ }^{97}$

\section{The Costs of Overuse}

As the colonial population of Australia continued to grow and expand geographically through the nineteenth century, the environmental toll of colonization became ever more apparent. The British focus on monocrop agriculture and livestock husbandry produced problems noted by settlers and colonial officials alike, including soil degradation and water pollution due to

\footnotetext{
94 Townend, Autobiography of the Rev., 127.

95 Booth, Australia, 33.

${ }^{96}$ Marsden, Life of the Reverend, 238; Roberts, Massacres to Mining, 22; Townend, Autobiography of the Rev., 199-200.

${ }^{97}$ Booth, Australia, 3.
} 
extensive erosion, scarcity of clean water, and unsustainable changes to native forest and grassland ecosystems. Even early explorers noted the lack of permanent bodies of freshwater and the difficulty of finding potable water for large groups, instead finding saltwater creeks and marshes. ${ }^{98}$ Settler photographs help illustrate the dramatic changes occurring after British arrival while also illuminating the appropriation of the Australian landscape for colonial agricultural purposes. Australia became a British entity on maps and in narrative accounts, while photos revealed the colonizing perspective of settlers who viewed the land as a canvas awaiting transformation. Descriptions of "uncleared virgin land" and the "wild neglected park" spoke not only to the common notion of an untouched wilderness but also glossed over the Aborigines and their role in shaping the environment. ${ }^{99}$

These forested "parklands" were located in regions that had semipredictable climate patterns, usually paralleling the coasts. Aborigines used fire to remove extensive forest undergrowth in these regions, allowing for easier movement and hunting of prey, but the pervasive environmental degradation of intense agricultural production left the ground exposed to erosion that removed productive topsoil and rendered hundreds of acres useless.

The expansion of European towns combined with intensified agricultural production to produce extensive environmental transformations across the continent. Settlers turned the eucalyptus forests, shrub-covered hills, and grassy floodplains familiar to the Aborigines into pastures and crop fields or stations and towns. To prepare an area for farming or livestock production, settlers would clear the landscape of all trees and shrubs, creating a denuded, open field that suffered from extensive erosion during heavy rainfall. Erosion was particularly a problem in western Australia, where the wet season would bring torrential rainstorms that resulted in significant flooding. The lack of effective land-management by early settlers compacted soils and killed the native grasses that had previously prevented erosion. ${ }^{100}$ The native vegetation in the interior of Australia presented little challenge to settlers clearing land, thereby allowing massive tracts to be cleared relatively quickly then left alone in wait for planting later in the season. Large trees along rivers and the forested stretches along the coasts could be obstacles, but the lack of shrubs and other interwoven forest

\footnotetext{
${ }^{98}$ Leichhardt, Journal of an Overland Expedition, 191; Mitchell, Journal of an Expedition in the Interior of Tropical Australia, 12; Sturt, Journal of the Central Australian Expedition, 48.

99 Townend, Autobiography of the Rev., 155.

100 Macintyre, A Concise History of Australia, 58.
} 
foliage allowed for quick and efficient work that contributed to significant shifts from forest to barren scrub ecosystems. ${ }^{101}$

The scale of environmental modifications occurring throughout the continent was not lost on the settlers, as evidenced by the presence of comparative photos taken at a dividing line between settled property and wilderness. The dramatic changes to the landscape are easily seen as the land is cleared and planted with foreign crops, where photographers recognized the dichotomy between colonized and un-colonized landscapes. Any recognition of the problems associated by dramatic environmental change, however, was overshadowed by the celebration of development and progress, of taming the wilderness to suit the needs of the settlers and transforming a formerly empty land into a productive British colony.

Environmental degradation was the result of the combined forces of climate patterns, landscape characteristics, and human modification. These three categories were in place as soon as large-scale agricultural production became commonplace in the Australian colonies, around 1892.102 Droughts and flash flooding contributed to noticeable erosion on recently cleared land as well as along settled riverbanks. Winds blew away productive soil and torrential rains clogged rivers with sediment washed off exposed fields and riverbanks. Irrigation drained freshwater resources and promoted soil salinization, while livestock herds out-competed native fauna for forage. The overwhelming focus on economic production and expansion meant ecosystem vitality was far from a primary concern.

The problem of securing reliable water resources was only one of many settler concerns that produced extensive contemporary ramifications. Challenging weather patterns of drought and flooding made the preservation of clean water even more difficult, especially because many lakes and rivers either dried up or turned into salt marshes as precipitation fluctuated. ${ }^{103}$ Once the riverbanks and coastal zones were settled, water availability became the primary limitation on agricultural and urban expansion until technological innovations overcame environmental limits.

Extensive deforestation, especially along the originally densely forested coastal regions, led to the fragmentation of ecosystems that persists today.

\footnotetext{
101 Tench, Narrative of the Expedition to Botany Bay, 54.

${ }^{102}$ Coghlan, A Statistical Account, 185-186.

${ }^{103}$ Knight, Western Australian Year Book, 3-4.
} 
Rates of deforestation were particularly high in areas conducive to intensive agricultural production, such as along coasts and major rivers or areas of prolonged European settlement. It is worth noting that the areas not used for agricultural purposes contained poor soils, lacked enough precipitation, or were regions consisting mostly of sand or rock. Locations with these characteristics were not favorable for much vegetation growth and were settled last, if at all. The plants and animals found under such conditions are much more susceptible to disruption and less likely to recover, making them unreliable resources. The Aborigines recognized the fragile and unreliable nature of arid ecosystem species, choosing instead to rely on species with the capability to withstand extraction and disruption to avoid the risk of jeopardizing future resources. As the British colonies and their influence expanded beyond regions of reliably high precipitation and agriculturally productive soils, native species and the Aborigines were caught between an unwelcoming, regimented European landscape and climate zones where survival was not possible.

\section{Conclusion}

From millions or hundred-thousands of Aborigines to several thousand, from arid scrub, free-flowing rivers, and tropical forests to fenced-in towns and monoculture fields, the British colonization of Australia dramatically changed the environmental and sociocultural framework of the continent. The Aborigines continue to be a marginalized minority, struggling with identity and equality, while commercial agriculture and other pursuits persist in degrading the ecosystems, soils, and waterways upon which modern economic success depends. With the intensifying effects of climate change, Australia's modified ecosystems are facing serious challenges that technological innovations may not be able to halt or repair.

Land is the foundation, literally and figuratively, of any people. The goods and services derived from the landscape are not only the source of life, livelihood, and income, but also provide cultural identity and spiritual richness. Before the arrival of the British, the Aborigines understood and recognized the connection between humans and the land and incorporated it into their lives and land management practices. Groups, separated by language and kinship ties, maintained an itinerant tradition that gave natural resources time to recover in between periods of intense use. Fire was used to flush out prey and influence plant communities for better foraging. Both techniques respected the limits of the landscape and worked within its barriers for the best results. Such 
intimate knowledge of the land formed a central tenet of the Dreaming, which also provided social codes, laws, and customs that made up the Aborigines' identities. Ancestral spirits connected with the energies of the land and of individuals, weaving a rich tapestry of interrelations that made the landscape more than a simple repository of resources. It is true that the Aborigines changed the flora and fauna of Australia; they focused on providing for their own needs over preserving the natural state of the environment. A crucial difference between the Aborigines and later settlers was that the Aborigines were also aware that to completely alter existing ecosystems would mean destroying themselves as well.

A critical modern lesson in contrasts begins on August 22, 1770, when Lieutenant James Cook claimed Australia for Britain. Eight years later the First Fleet initiated the beginnings of European immigration that resulted in Australia's official inclusion as part of the British colonial empire in 1788. Focused on providing resources for Britain and welcoming thousands of immigrants, colonial Australia had little room for or interest in incorporating the Aborigines. The influx of settlers in the mid-nineteenth century, evolving from convicts and single men to middle-class families, further strengthened Britain's control of the continent and its land. As settlers built and expanded towns, ports, and farms, the Aborigines lost their territories through trades, charters, and colonial militias while disease and violence decimated the Aborigine population. Throughout the years of upheaval, the prevailing British perspective of Australia was of a terra nullius, or "empty continent," ready to be incorporated into the imperial British system of formal property ownership and economic production. Individual property ownership was not only a potential source of income from agricultural pursuits, but also became a source of social and political status. In the British view, the unruly wilds of the continent needed to be tamed and channeled toward the production of monocrops or livestock as part of an ongoing pursuit of social, cultural, and economic progress. Technology overcame the limits of arid climates, while the opportunity for social mobility promoted a steady stream of new arrivals. Australia changed from a land of itinerant hunter-gatherers into a land of commercialized production around urban centers, at the expense of the resilience and survival of the ecosystem and the future of a self-sustaining culture. Even in the early nineteenth century, settlers noticed the effects of focused production from the use of techniques imported from more temperate climates: erosion, shrinking surface water sources, water pollution, and soil salinization. Forests were cleared in favor of farms and pasture, while scrubland was irrigated for maize 
and cotton. The balanced connection between human action and ecosystem integrity, carefully maintained by the Aborigines, weakened with these changes. Australia in the twenty-first century faces the increasingly severe environmental effects of colonization with its commercialized production and the loss of knowledge of the landscape. Today, there are many national parks and cultural sites that offer a glimpse into what British explorers saw as they ventured across the continent in the nineteenth century. These locations are valuable not only for discerning what the continent was like under the Aborigines' management prior to the arrival of the British, but also for providing sites where flora and fauna can flourish without competing against crops or expanding urban centers.

The history of Australia's settlement and alteration, revealed through explorer reports and settler photographs, shows the changes that catalyzed the environmental problems facing Australians today. As the effects of climate change continue to intensify across the continent, it is not possible to return to past conditions and their equilibrium. The mobile-use lifestyle of the Aborigines prior to British colonization would not work in the contemporary world simply because there are too many people to give regions the time to recover. There are some lessons, however, that can be adapted from their original forms employed by the Aborigines and applied: growing native crops in pastures and smaller agricultural plots to reduce erosion from denuded fields of introduced grasses; decreasing the amount of water used in irrigation; respecting the limits of arid or nutrient-poor regions and reducing their use or halting their development for agriculture; and employing resource-efficient technologies to reduce the amount of energy and water used in urban areas. These are not simple or easy solutions, as they require sacrifice and flexibility while markets reshape themselves to fit the limits of the environment they rely on. The Aborigines understood that humans were not isolated or separated from the environment and its limitations. To degrade the environment is to degrade our future livelihoods. It is a lesson that bears relearning and repeating for the benefit of all who wish to survive and thrive in an increasingly changed world. 


\section{Appendix}

\section{Timeline}

1768

Lieutenant James Cook lands on the eastern coast of Australia

August 22, 1770 Cook claims Australia for Britain

1786

Captain Arthur Phillip appointed Governor of Australia

October 12, 1786 Australia becomes an official part of the British colonial empire

1788

First ship of convicts and laborers arrives at Botany Bay colony in southeast Australia

January 26, 1788 City of Sydney founded

February 7,1788 New South Wales proclaimed a colony

Smallpox epidemic

1803

First attempt to settle Victoria abandoned

1810

Lachlan Macquarie appointed first Governor of New South Wales

May 2, 1816 Governor Macquarie issues proclamation on using terror against the Aborigines

May 4, $1816 \quad$ Governor Macquarie issues proclamation prohibiting armed Aborigines from approaching within one mile of British settlements

Eagle Farm established as the first penal settlement

Sydney founded on the southeastern coast

1827

Colony of Western Australia established

1829

Perth founded

Smallpox epidemic

June 1, 1829

Colony of Swan River founded

Swan River territory extended to the $129^{\circ}$ longitude line 
Name of "South Australia" adopted for a territory separate from the territory of Victoria

Territory of Victoria colonization begins

1835

John Batman's land conveyance agreement signed by seven leaders of the Kulin Aborigine people

1836

City of Adelaide founded

December 28, 1836 Colony of South Australia established

1837

1840

1842

1850

1851

1859

1861

1863
Melbourne founded

Transport of convicts to New South Wales abolished

South Australia made into a crown colony

Moreton Bay district open to free settlement, end of Eagle Farm penal settlement

Gold rush in Victoria

First Aborigine reservations created by the Australian government

Port Phillip separates from New South Wales and declared the Colony of Victoria

Moreton Bay district in Queensland separates from New South Wales

Queensland declared an independent colony

Passage of the Crown Lands Alienation Act, which opened up Australia to widespread settlement Second gold rush in Victoria

Northern Territory of South Australia formalized 


\section{Works Cited}

\section{Primary Sources}

Barrow, John. "State of the Colony of Swan River." Journal of the Royal Geographical Society of London 1 (1831): 1-16. Accessed March 31, 2013. http://www.jstor.org/stable/1797655.

Batman, John. Document known as the "Batman Land Deed," between John Batman and Aboriginal "Chiefs" of the Kulin nation, Port Phillip area, 1835. Port Philip: Port Philip Association, 1835. Accessed July 9, 2014. http://trove.nla.gov.au/version/13556934.

Buckley, William and George Langhorne. Reminiscenses of James Buckley who lived for thirty years among the Wallawarro or Watourong tribes at Geelong Port Philip, communicated by bim to George Langhorne. 1837. Accessed March 27, 2014.

http://www.cv.vic.gov.au/stories/immigrants-and-emigrants/williambuckley/reminiscenses-of-james-buckley-who-lived-for-thirty-years-among-thewallawarro-or-watourong-tribes/.

Coghlan, Timothy Augustine. A Statistical Account of the Seven Colonies of Australasia. Sydney: Charles Potter, 1894. Accessed July 11, 2014.

https:/ / babel.hathitrust.org/shcgi/pt?id=uc1.b3292507;view=1up;seq =5.

"Colonel Hansons Pamphlet." The Perth Gazette and Western Australian Journal. January 12, 1833. Accessed September 26, 2013.

http://trove.nla.gov.au/ndp/del/page/7?zoomLevel=1.

Cook, James. Captain Cook's Journal During His First Voyage Round the World Made in H. M. Bark "Endeavour" 1768-71 - Literal Transcription of the Original MSS. With Notes and Introduction. Edited by W. J. L. Wharton. London: Elliot Stock, 1893. Accessed March 13, 2014. http://www.gutenberg.org/files/8106/8106-h/8106h.htm\#ch8.

Knight, Godfrey Charles. Western Australian Year Book for 1886 (First Year of Issue). Perth: Richard Pether, 1887. Accessed July 11, 2014.

http://www.abs.gov.au/AUSSTATS/abs@.nsf/DetailsPage/1300.51886?Open Document.

Leichhardt, Ludwig. Journal of an Overland Expedition in Australia: From Moreton Bay to Port Essington, a Distance of Upwards of 3000 Miles, During the Years 1844-1845. London: T. and W. Boone, 1847. Accessed January 22, 2014. http://purl.library.usyd.edu.au/setis/id/p00050.

Marsden, Samuel. Memoirs of the Life and Labours of the Rev. Samuel Marsden, of Paramatta, Senior Chaplain of New South Wales; and of his Early Connexion with the Missions to New Zealand and Tahiti. Edited by John Buxton Marsden. London: The Religious Tract Society, 1858. Accessed January 13, 2014. http://hdl.handle.net/2027/uc2.ark:/13960/t3jw8f169.

Mitchell, Thomas Livingstone. Journal of an Expedition in the Interior of Tropical Australia: In Search of a Route from Sydney to the Gulf of Carpentaria. London: Longman, Brown, 
Green, and Longmans, 1848. Accessed March 30, 2014.

http://purl.library.usyd.edu.au/setis/id/mitjour.

Oxley, John Joseph William Molesworth. Journals of Two Expeditions into the Interior of

New South Wales: Undertaken by Order of the British Government in the Years 1817-18.

London: John Murray, 1820. Accessed January 22, 2014.

http://purl.library.usyd.edu.au/setis/id/p00066.

Roe, J. S. "Report of an Expedition Under the Surveyor-General, Mr. J. S. Roe, to the South-Eastward of Perth, in Western Australia, Between the Months of September, 1848, and February, 1849, to the Hon. The Colonial Secretary." Journal of the Royal Geographical Society of London 22 (1852): 1-57. Accessed February 18, 2013. http://www.jstor.org/stable/1798198.

Salvado, Rosendo, and Charles Henry Edward Carmichael. A Benedictine Missionary's Account of the Natives of Australia and Oceania: From the Italian of Don Rudesindo Salvado. (Rome: 1851). London: Anthropological Institute, 1878. Accessed March 25, 2014. http://tinyurl.galegroup.com/tinyurl/EQ8T4.

Statement on the Land Laws by the Council of the Incorporated Law Society of the United Kingdom. London: Spottiswoode and Company, 1886. Accessed July 24, 2014. http://www.jstor.org/stable/60217977.

Sturt, Charles. Journal of the Central Australian Expedition 1844-1845 and An Account of the Sea Coast and Interior of South Australia. Edited by Jill Waterhouse. London: Caliban Books, 1984.

Tench, Watkin. A Narrative of the Expedition to Botany Bay, With an Account of New South Wales, Its Productions, Inhabitants, \&c. To Which is Subjoined, A List of the Civil and Military Establishments at Port Jackson. London: J. Debrett, 1789. Accessed June 26, 2014. http://purl.library.usyd.edu.au/setis/id/p00039.

Townend, Joseph. Autobiography of the Rev. Joseph Townend: With Reminiscences of His Missionary Labours in Australia. London: W. Reed, 1869. Accessed February 12, 2014. http://tinyurl.galegroup.com.proxy.lib.uiowa.edu/tinyurl/Ep4h0.

\section{Secondary Sources}

"Aboriginal Bush Foods." The Royal Botanic Gardens and Domain Trust. Accessed July 28, 2014. http://www.rbgsyd.nsw.gov.au/plant_info/aboriginal_bush_foods.

"Aboriginal Customary Laws and Anglo-Australian Law after 1788." In Recognition of Aboriginal Customary Laws (ALRC Report 31), 28-41. Sydney: Australian Government, 1986. Accessed July 24, 2014. http://www.alrc.gov.au/sites/default/files/pdfs/publications/ALRC31.pdf.

“Aboriginal Rock Art.” Glenelg Hopkins. Accessed July 28, 2014.

www.ghcma.vic.gov.au/community/cultural-heritage/aboriginal-tools/aboriginalrock-art/. 
Atkinson, Alan. "Conquest." In Australia's Empire, edited by Deryck M. Schreuder and Stuart Ward, 33-53. Oxford: Oxford University Press, 2008.

Banner, Stuart. Possessing the Pacific: Land, Settlers, and Indigenous People from Australia to Alaska. Cambridge: Harvard University Press, 2007.

Booth, Edwin Carton. Australia. London: Virtue and Company, Ltd., 1876. Accessed June 13, 2014.

https://ia802709.us.archive.org/23/items/australia02boot/australia02boot.pdf.

Bull, John Wrathall. Early Experiences of Life in South Australia, and An Extended Colonial History. Adelaide: E. S. Wigg and Son, 1884.

Curthoys, Ann. “Indigenous Subjects.” In Australia's Empire, edited by Deryck M. Schreuder and Stuart Ward, 78-102. Oxford: Oxford University Press, 2008.

David, Bruno. Landscapes, Rock-Art, and the Dreaming: An Archaeology of Preunderstanding. London: Leicester University Press, 2002.

“Document known as the 'Batman Land Deed,' between John Batman and Aboriginal 'chiefs' of the Kulin nation, Port Phillip area, 1835." National Museum of Australia. Accessed July 9, 2014.

http://collectionsearch.nma.gov.au/?object $=58198$.

"European Discovery and the Colonisation of Australia." Australia.gov.au. Accessed August 23, 2013. http:/ / australia.gov.au/about-australia/australianstory/european-discovery-and-colonisation.

Foley, Jonathan A., Ruth DeFries, Gregory P. Asner, Carol Barford, Gordon Bonan, Stephen R. Carpenter, F. Stuart Chapin, Michael T. Coe, Gretchen C. Daily, Holly K. Gibbs, Joseph H. Helkowski, Tracey Holloway, Erica A. Howard, Christopher J. Kucharik, Chad Monfreda, Jonathan A. Patz, I. Colin Prentice, Navin Ramankutty, and Peter K. Snyder. "Global Consequences of Land Use." Science 309 (2005): 570-574. Accessed March 8, 2013. doi: 10.1126/science.1111772.

Gammage, Bill. Biggest Estate on Earth: How Aborigines Made Australia. Sydney: Allen and Unwin, 2011.

Grant, Robert D. Representations of British Emigration, Colonisation and Settlement: Imagining Empire, 1800-1860. Houndmills: Palmgrave Macmillan, 2005.

Hume, Lynne. Ancestral Power: The Dreaming, Consciousness and Aboriginal Australians. Carlton South: Melbourne University Press, 2002.

King, Joseph. Ten Decades; The Australian Centenary Story of the London Missionary Society. London: London Missionary Society, 1895.

Kohen, James L. Aboriginal Environmental Impacts. Sydney: University of New South Wales Press, 1995.

Langton, Marcia. "Earth, Wind, Fire, and Water: The Social and Spiritual Construction of Water in Aboriginal Societies." In The Social Archaeology of Australian Indigenous Societies, edited by Bruno David, Bryce Barker, and Ian J. McNiven. 139-160. Canberra: Aboriginal Studies Press, 2006. 
Macintyre, Stuart. A Concise History of Australia. Cambridge: Cambridge University Press, 2004.

Price, Archibald Grenfell. White Settlers and Native Peoples: An Historical Study of Racial Contacts Between English-Speaking Whites and Aboriginal Peoples in the United States, Canada, Australia and New Zealand. Melbourne: Georgian House, 1950.

Roberts, Jan. Massacres to Mining: The Colonisation of Aboriginal Australia. Blackburn: Dove Communications, 1981.

Servello, Susan. "Australian Aborigines." In 215t Century Anthropology: A Reference Handbook. Edited by H. James Birx. Thousand Oaks: SAGE Publications, Inc., 2010. Accessed September 28, 2013. doi:

http://dx.doi.org.proxy.lib.uiowa.edu/10.4135/9781412979283.n66.

"Settled Land Act of 1882." The National Archives. Accessed July 24, 2014. http://www.legislation.gov.uk/ukpga/Vict/45-46/38/enacted.

Stirling, Ros. "Gariwerd: Summits Old in Story.” Australian Heritage. Accessed July 29, 2014. http://www.heritageaustralia.com.au/magazine.php?article $=429$.

Strachan, Alexander. The Life of the Rev. Samuel Leigh, Missionary to the Settlers and Savages of Australia and New Zealand; with a History of the Origin and Progress of the Missions in those Colonies. London: Wesleyan Mission House, 1870. Accessed March 29, 2014. University of California.

http://babel.hathitrust.org/cgi/pt?id=uc2.ark:/13960/t8cf9n906;view=1up;seq= 7.

Waterhouse, Richard. "Settling the Land.” In Australia's Empire, edited by Deryck M. Schreuder and Stuart Ward, 54-77. Oxford: Oxford University Press, 2008.

Weaver, John C. "Beyond the Fatal Shore: Pastoral Squatting and the Occupation of Australia, 1826 to 1852." The American Historical Review 101 (1996): 981-1007. Accessed July 29, 2014. doi: 10.2307/2169631.

"What is an El Niño?" National Oceanic and Atmospheric Administration. Accessed April 25, 2015. http://www.pmel.noaa.gov/tao/elnino/el-nino-story.html. 